\title{
Equity and the Cuban National Health System's response to COVID-19*
}

\author{
Pedro Mas Bermejo, ${ }^{1}$ Lizet Sánchez Valdés, ${ }^{2}$ Lorenzo Somarriba López, ${ }^{3}$ \\ Nelly Cristina Valdivia Onega, ${ }^{4}$ María Josefina Vidal Ledo, ${ }^{5}$ Ileana Alfonso Sánchez, ${ }^{6}$ \\ Armando Seuc Jo, ${ }^{7}$ Yudivian Almeida Cruz, ${ }^{8}$ and Roberto Morales Ojeda ${ }^{8}$
}

Suggested citation Mas Bermejo P, Sánchez Valdés L, Somarriba López L, Valdivia Onega NC, Vidal Ledo MJ, Alfonso Sánchez I, et al. Equity and the Cuban National Health System's response to COVID-19. Rev Panam Salud Publica. 2021;45:e80. https://doi.org/10.26633/RPSP.2021.80

ABSTRACT Cuba's National Health System has managed to guarantee an effective and equitable response to COVID-19. Universal and free health coverage, based on primary care, follows the principle of equity and the greatest resources are allocated to areas of the lowest socioeconomic stratum (where higher risk is concentrated), followed by those of medium and high strata, in that order. This allowed for similar mortality rates in the three strata, and Cuban national mortality rate was one of the lowest in the Region of the Americas. Before the first case was identified in Cuba, a Plan for Coronavirus Prevention and Control was elaborated with multisectoral participation, and when the first case was confirmed the Temporary National Working Group to Fight COVID-19 was created as an advisory body of the government. The actions to face the pandemic began with preventive measures in the community, continued in the isolation centers and ended again in the community with actions of surveillance and follow up of recovered patients. Following the principle of territoriality, molecular diagnosis laboratories were created in the provinces that did not have one. Free medical care and treatment; the preparation of a single national intersectoral government plan; the use of particular strategies for research, diagnosis and case tracing; and the implementation of a universal protocol for disease prevention and treatment of confirmed cases made it possible to control the disease with a health equity perspective.

Keywords Coronavirus infections; health equity; universal health coverage; primary health care; Cuba.

Equity is a complex concept with a long history. The word has had various definitions, ultimately going back to the Latin aequitas, referring to justice (1). Today, achieving equity in health means that people are able to develop their maximum health potential regardless of their social status or other circumstances determined by social factors. More specifically, it means that resources are allocated according to need; processes are administered with justice; and discrimination is avoided in the delivery of care $(2,3)$.

As of 1 October 2020, the COVID-19 pandemic caused by the SARS CoV-2 coronavirus had caused more than 34 million confirmed cases and 1 million deaths, corresponding to an estimated case-fatality rate (number of deaths in the cumulative total of positive cases) of $2.98 \%$. The countries in the Region

\footnotetext{
Official English translation from the original Spanish manuscript made by the Pan American Health Organization. In case of discrepancy, the original version shall prevail. Access to original manuscript: https://doi.org/10.26633/ RPSP.2020.138

1 Pedro Kouri Institute of Tropical Medicine, Havana, Cuba. $\square$ Pedro Mas Bermejo, pmasbe@infomed.sld.cu

Molecular Immunology Center, Havana, Cuba.
}

\footnotetext{
2 Ministry of Public Health, Havana, Cuba.

3 La Pradera International Health Center, Havana, Cuba.

4 National School of Public Health, Havana, Cuba.

5 National Medical Sciences Information Center, Havana, Cuba.

6 National Institute of Hygiene, Epidemiology, and Microbiology, Havana, Cuba.

7 Council of Ministers, Havana, Cuba.
} 
of the Americas had reported more than 16 million confirmed cases and more than 560000 deaths, for a case-fatality rate of $3.33 \%$. This onslaught has severely tested the capacity of health systems throughout the world (4).

Addressing this pandemic requires not only adequate hospital and laboratory infrastructure but also health systems that have sufficient health personnel and equipment to trace confirmed cases and at the same time treat the excessive number of patients. Meanwhile, as with other infectious diseases, inequities are aggravating both the transmission of COVID-19 and the severity with which it is assailing the poorest societies (5). Thus, the consequences of the disease are disproportionally affecting vulnerable groups and those who suffer from discrimination. Faced with this reality, the Pan American Health Organization (PAHO) has appealed to the countries of the Region to focus on the equity perspective and the factors of gender, ethnic characteristics, and human rights in their responses to COVID-19 (6).

For Cuba, equity, social justice and the promotion of social and human development are basic pillars of social policy (7) enshrined in the Constitution of the Republic, which also emphasizes that public health is the right of all people and that the State is responsible for guaranteeing free access to quality health care, protection, and rehabilitation services (8).

In a recent process of updating the Cuban economic model, major changes in the health sector have involved redefining functions and structures at all levels of care throughout the country $(9,10)$. This initiative has produced a service organization that has proven to be capable of addressing disasters and extraordinary situations-in particular, the COVID-19 pandemic.

As of 1 October 2020, Cuba had recorded a total of 5670 confirmed cases. Of this number, 5078 of the patients had recovered, 518 were still hospitalized, and 122 people who tested positive for SARS-CoV-2 had died, representing a case-fatality rate of 2.15, one of the lowest in Latin America (4).

The present study aims to show how the Cuban National Health System (known by its Spanish acronym, SNS) has been able to ensure an effective and equitable response to COVID-19.

\section{EQUITY IN THE PRIMARY CARE-BASED HEALTH SYSTEM}

In the Cuban SNS, equity is taken as a premise for ensuring that health care is efficient and meets the needs of society based on the principles of free and effective access to services, disease prevention, strong community participation, and intersectorality. It is a centralized system in normative and methodological terms, but it is decentralized in the execution of its programs and actions, which incorporate up-to-date scientific and technological advances. It also engages in international cooperation with countries that need and request it (11).

Universal SNS coverage is based on the primary health care (PHC) strategy and on a single integrated public model with service delivery networks organized by levels of care and by policies and programs that focus on epidemiology, environmental health, and medical care. Within this network, actions are coordinated and public health functions are fulfilled based on the determinants that affect the health status of the population. Both within the sector and at the social level, emphasis is placed on health promotion and disease prevention, always bearing in mind the principle of intersectorality (12).
Another strength of the SNS is its programmatic approach, which makes it possible to spell out the steps for leading patients through the service network within each region. The staff of 479 623 health workers, distributed across the three levels of care, are interconnected through a referral and back-referral system. At the center is the family doctor, who follows each patient, receiving ongoing updates, as he or she goes through the network (13).

Thus, the primary care system, based on community family medicine clinics, is linked to the second level of care, which has 150 municipal hospitals that offer all the specialties, including 110 hospital intensive care units. The third level of care consists of 12 specialized research institutes that also provide care. All citizens have free access to all these health facilities, from primary care to the highest degree of specialization at the third level of care. Together, these institutions function as part of an overall process of regionalization of the services, both geographically and in terms of specialized care, thus representing a true expression of equity in terms of access and opportunities (13).

Among other key processes, the Cuban family medicine model includes dispensation and ongoing oversight and analysis of the health situation, which makes it possible to identify individuals and families in vulnerable circumstances. In this important way, the model defines the needs for resources to improve the health of the community. The family doctor and the nurse, through their authority and their connections with local government leaders and community organizations, have the opportunity to modify behaviors and affect the perception of risk in the population under their care. At the same time, there are also cultural and socioeconomic differences within the country that make for geographic variations in living conditions. In earlier studies (14), Cuba's 15 provinces and the Isla de la Juventud Special Municipality were classified according to the following three strata based on the Living Conditions Index: lower $(<0.40)$, intermediate (0.41-0.55), and high (>0.55). Specifically, the country's eastern provinces (Las Tunas, Holguín, Granma, Santiago de Cuba, and Guantánamo) are in the low stratum, while some of the provinces in the western and central parts (Pinar del Río, Mayabeque, Matanzas, Villa Clara, and Sancti Spíritus) are in the intermediate stratum, and the rest (Artemisa, La Habana, Cienfuegos, Ciego de Ávila, Camagüey, and the Isla de la Juventud Special Municipality) are in the high stratum.

The SNS constantly works to develop its human resources and improve its services. This effort has made it possible to steadily improve the main health indicators and the health status of the population (15). In keeping with the principle of equity, it allocates the largest proportion of human and material resources to the lowest stratum, where health risks are most concentrated, followed by the intermediate and the high strata, in that order. When it comes to COVID-19, however, Table 1 shows that transmission of the disease has mainly affected the highest stratum, which includes the national capital.

\section{PREPARATIONS TO TACKLE COVID-19 IN CUBA}

In January 2020, the Cuban Government, working through the Ministry of Public Health with the participation of all the affected social and economic sectors, established a Temporary National Working Group to Fight COVID-19 and launched a major government effort to mobilize the needed scientific, technological, and professional capacity to tackle the pandemic. The 
TABLE 1. National COVID-19 statistics by strata, Cuba, as of 1 October 2020

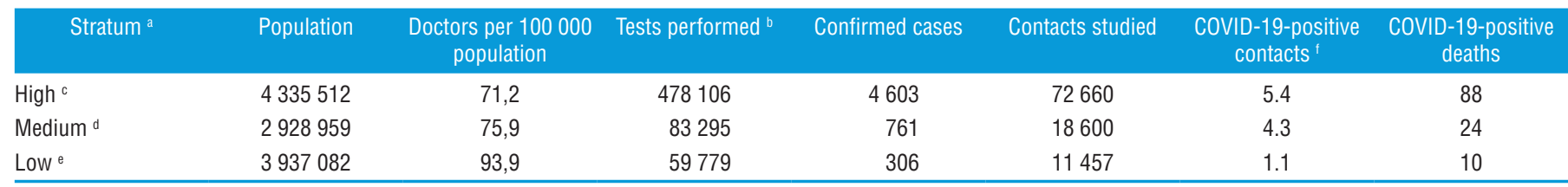

Source: Own preparation.

Strata based on the Living Conditions Index: low (<0.40); intermediate (0.41-055); high (>0.55) (14).

Real-time polymerase chain reaction (RT-PCR) test.

Provinces of Artemisa, La Habana, Cienfuegos, Ciego de Ávila, and Camagüey and the Isla de la Juventud Special Municipality.

Provinces of

Average per confirmed case.

details were embodied in a Plan for Coronavirus Prevention and Control (16), which sets forth policies on governance, communication, and science and technology while also taking care to guarantee equity in applying public health measures as part of the strategies for addressing the task. Furthermore, under the Plan, human and material resources were put in place to accompany implementation and any adjustments needed to meet this challenge (17).

When the first imported cases appeared in March, decisions and action plans were implemented in every economic sector. At the same time, defense councils were called up in all the country's territories at the national, provincial, and municipal levels with an across-the-board mandate to emphasize an intersectoral approach. The job of these defense councils is to coordinate strategies and actions in the event of natural disasters, epidemics, and other extraordinary events that affect the community. In this case, they were tasked with coordinating and overseeing the missions and measures taken in each entity and community to shore up health promotion (information, education, and communication), encourage social distancing, monitor borders, mitigate risk factors, and ensure protection of the most vulnerable populations (18).

On 20 March, nine days after detection of the first imported cases, which came from Europe, the government announced new measures for tackling COVID-19 and mobilized the Temporary National Working Group to Fight COVID-19. The mission of this expert task force-made up of academics, other university specialists, and representatives of research centers and health care services-has been to provide advice and to collaborate with the government's top echelons in identifying the magnitude and spread of the disease in the country, the risks it poses, and its severity. The group has also provided criteria for assessing interventions, planning the use of resources, and analyzing the epidemiological situation in Cuba and in the international context. In addition, it has collaborated on the analysis and proposal of measures for combating the disease, the modeling of scenarios, and the creation of an interactive dashboard for monitoring and controlling the epidemic (19-21).

With a view to ensuring equitable access to all information about the epidemiological situation, a system was established to communicate the most recent updates to the population. Since 11 March, when the first imported cases were detected, the mass media and social networks have broadcast daily reports from the Ministry of Health's National Director of Epidemiology, as well as prime-time televised segments, such as the "Roundtable Program," with the participation of the Minister of Public Health and other ministry officials, scientists, and high-ranking government leaders (22).

\section{ACTIVE CASE FINDING, DIAGNOSIS, CONTACT TRACING, AND ISOLATION}

Active case finding was entrusted to the basic health teamsstructures at the primary care level consisting of doctors, nurses, and specialists, with added support from students and teachers at the country's medical and health science schools, who incorporated these activities into their regular academic and continuing education programs. This ongoing systematic contact with the community facilitated the early and timely detection of positive cases, with or without symptoms, as well as efforts to track the epidemiological chain of transmission. Operations were strengthened at the primary care level (integrated into the rest of the system) through training and additional human resource development, making it possible to take immediate action, incorporate epidemiological search skills to identify direct contacts and vulnerable individuals, increase capacity to motivate and incorporate the community as the target for these measures, and manage service operations. These were all key steps toward achieving social effectiveness and meeting the needs of the population in the midst of a highly complex situation.

Use of the real-time polymerase chain reaction (RT-PCR) test was essential for confirming cases. Administration of these tests increased as the epidemic gained momentum, with a relatively uniform distribution across most of the regions. The main exception was the capital, which was the epicenter of the epidemic from the outset (Figure 1).

Initially, three laboratories were performing RT-PCR tests, one in each region of the country: in Havana, for the western provinces (Pinar del Río, Artemisa, Mayabeque, La Habana, and Matanzas provinces and Isla de Juventud Special Municipality); in Villa Clara, for the central provinces (Villa Clara, Cienfuegos, Sancti Spíritus, Ciego de Ávila, and Camagüey); and in Santiago de Cuba, for the eastern provinces (Las Tunas, Holguín, Granma, Santiago de Cuba, and Guantánamo). Later, as the epidemiological situation became more complicated in the western region, additional laboratories were set up in La Habana Province. It was also decided to develop a nationwide diagnostic network with the goal of having a molecular biology laboratory in each province. Existing laboratories were instructed to operate in shifts around the clock; their equipment was upgraded; and diagnostic capacity was increased through training programs. These measures enabled each province to process as many tests as it needed, depending on its epidemiological situation. Between 11 March and 30 September 2020, a total of 621 180 samples were analyzed (55 410 tests per million population).

For each confirmed case in the country, first- and seconddegree contacts were identified and isolated. All were tested 
FIGURE 1. Distribution of confirmed COVID-19 cases and number of PCR a tests administered by Living Conditions Index strata, ${ }^{b}$ Cuba, 1 October 2020
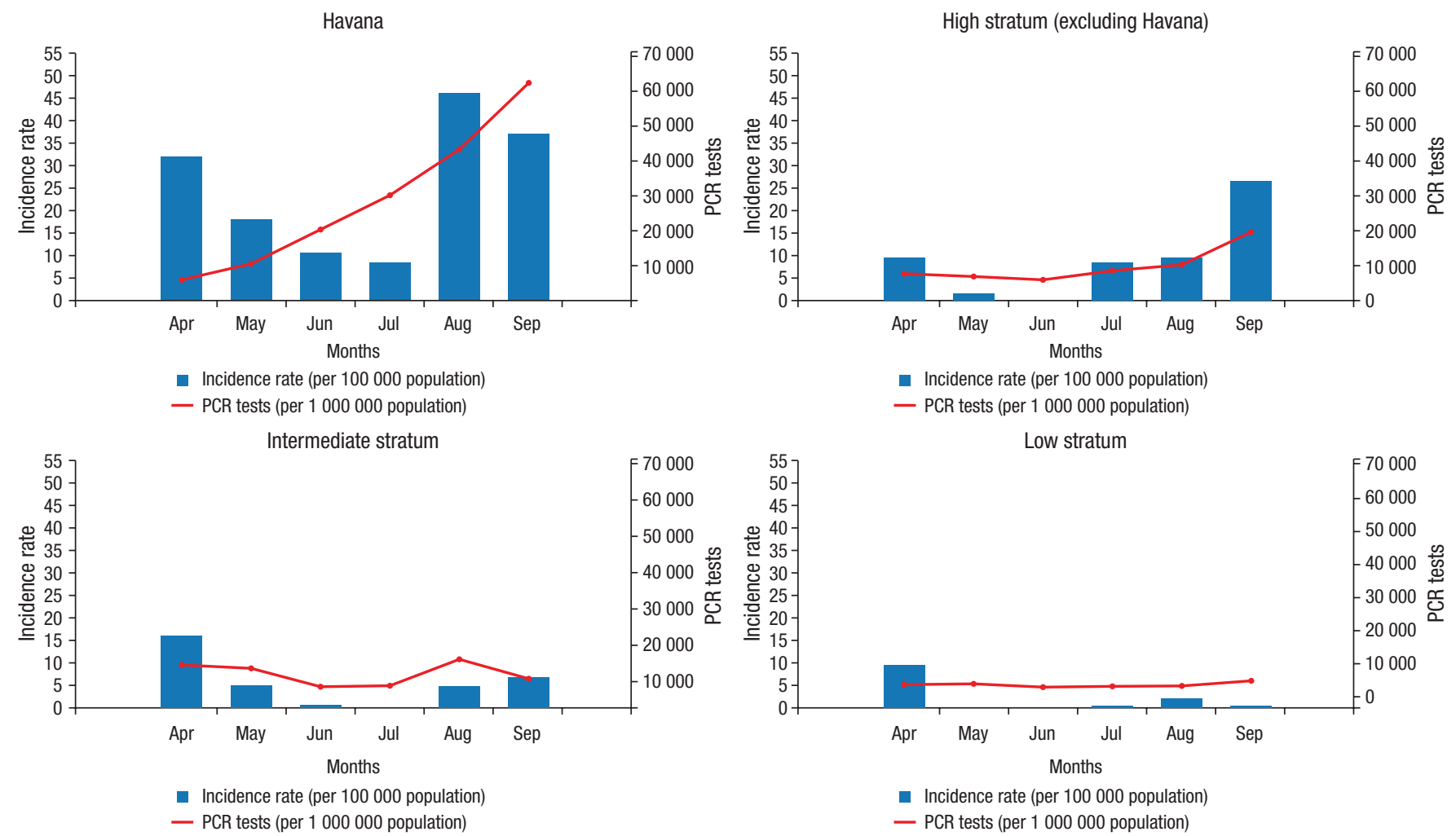

Source: Own preparation based on data from: https:Itcovid19cubadata.github.iof\#cuba.

a RT-PCR: real-time polymerase chain reaction tests.
b Strata based on the Living Conditions Index: low (<0.40); intermediate (0.41-055); high (>0.55) (14); see further information in footnotes to Table 1.

for possible SARS-CoV-2 infection. As the situation continued to evolve, an intersectoral effort was mounted to set up new health care facilities apart from the regular health system's existing facilities in all the provinces and Isla de la Juventud Special Municipality. In total, the following additional facilities were made available: 1103 new beds in centers designed to care for low-risk suspected cases, 3636 beds in surveillance centers for contacts of confirmed cases, and 4039 beds in centers for monitoring travelers. A suspected case was defined as any person presenting a clinical manifestation suggestive of COVID-19, including fever, dry cough, gradually increasing shortness of breath or other respiratory symptom, weakness, general malaise, headache, diarrhea, or loss of sense of smell or taste. In this way, it was possible to deploy additional service infrastructure without overtaxing the regular health system (22).

In addition, to study the extent to which the disease has spread in the country, a seroprevalence survey was initiated in all the provinces, including municipalities that may not have reported any positive cases. The project calls for studying a representative sample of the population based on testing approximately 4000 individuals and 1400 households. It is being conducted in four stages and is yet to be completed.

\section{PREVENTION OF INFECTION AND CARE OR CONFIRMED PATIENTS}

Confirmed patients were hospitalized until their RT-PCR test was negative for COVID-19, following which they were quarantined at home for 14 days under surveillance by the family medical doctor. All received the protocol adopted in Cuba for treating the disease (23). There is a single standard protocol and it is applied nationwide. In other words, it is used in all health institutions in the country and at all levels of care. However, it is flexible in that it can be adapted to the clinical status of each patient and the disease's evolution. It is regularly updated as new scientific evidence on SARS-CoV-2 becomes available in Cuba and the rest of the world.

The priorities under the Cuban protocol are preventing infection, controlling the disease, ensuring the best possible case management, and protecting health workers and the population. As shown in Figure 2, actions aimed at tackling the pandemic in Cuba start first with preventive measures at the community level. At the next level, isolation centers are set up for suspected cases, contacts of individuals with confirmed or suspected cases, and travelers arriving in the country are monitored. Finally, the process circles back to the community with measures for the surveillance and follow-up of recovering patients.

Active house-to-house searching for suspected cases and testing of all case contacts have been key characteristics of the Cuban strategy for dealing with the epidemic. This approach has ensured more timely care, before complications start to develop. The groups at greatest risk in the Cuban population are the same as those reported in the international literature: people living in institutions, seniors 60 years and older, and those under 60 with chronic health conditions, the most 
FIGURE 2. Preventive and therapeutic measures adopted, from case detection to recovery of confirmed COVID-19 cases, Cuba, $2020^{\mathrm{a}}$

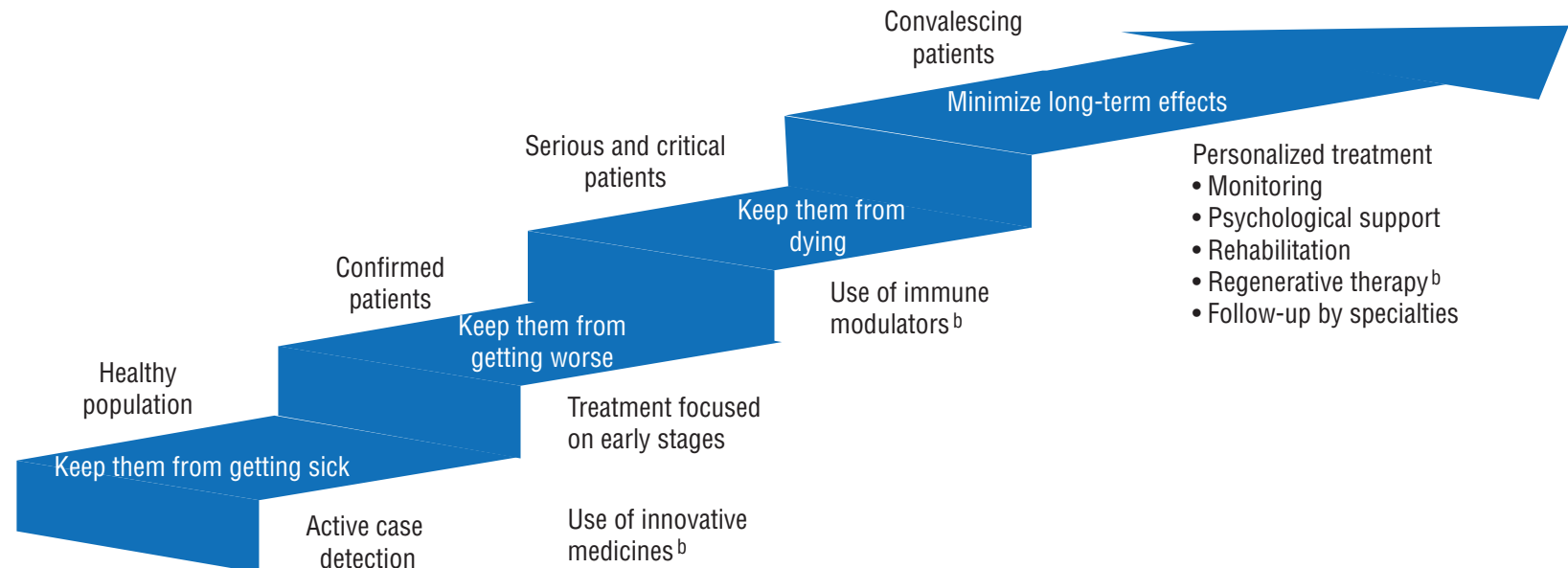

Automated case detection

Use of preventive medicines $^{b}$

Source: Prepared by the Science and Technology Directorate, Ministry of Public Health. From: Presentation by the Temporary National Working Group, 8 October 2020.

a The upper row corresponds to the target population in each phase; the blue strip shows the goal for this population, and the lower rows indicate the preventive and therapeutic measures adopted.

b Based mainly on medicines and biomolecular approaches developed in Cuba.

frequent of which are high blood pressure, diabetes mellitus, coronary heart disease, chronic obstructive pulmonary disease, and chronic kidney failure (24).

During the period from the start of the pandemic until 1 October, a total of 625 COVID-19 cases were detected in the population under 18 years old. The age-specific incidence rate increased significantly, from 22.4 per 100,000 infants under 1 year old to 33.19 per 100000 adolescents aged 15 to 18 $(p=0.02)$. Although this increase was higher than levels reported internationally (25), in most of the children the disease ran its course either asymptomatically or without complications. The high number of cases detected in the pediatric age group in Cuba may be related to the extensive case finding being conducted in the country and to the priority that the SNS assigns to its Maternal and Child Care Program. Cuba has established a surveillance system to raise the awareness of risk and promote early diagnosis of multisystem inflammatory syndromes and Kawasaki disease. This system made it possible to detect two children with these complications, both of whom were treated promptly and have recovered.

All diagnosed patients receive treatment free of cost in all the health institutions in the country. Most of the medicines (14 of the main 18 used) are produced nationally. The Cuban biotechnology industry has been responsible for guaranteeing access to all the products listed in the Cuban protocol, including innovative therapies that have proven to be effective in keeping patients from developing the more serious forms of the disease (26-30).

\section{MAIN RESULTS AND CURRENT SITUATION}

From the outset, the actions taken by the Cuban Government have focused on an intersectoral approach aimed essentially at mitigating the effects of the disease and interrupting the transmission of COVID-19. All these actions have been taken simultaneously and uniformly in all the provinces of the country through local governments and institutions.

Later, as the epidemic evolved, these measures were gradually "de-escalated," territory by territory. The Temporary National Working Group has been responsible for approving these changes, always following established criteria applied equally to all the provinces, thus demonstrating an example of equity in management of the epidemic by the central government and in the country's political direction.

The outcomes reported above are reflected in the Oxford COVID-19 Government Response Tracker (OxCGRT), also known as the Oxford Stringency Index, a tool developed by that Oxford University to assess the degree of government restrictiveness in the response to COVID-19 (31). As shown in Figure 3, the measures adopted Cuba in response to the epidemiological pattern of the disease were kept in place for one additional month. During that period, Cuba met the criteria for the highest rating on the scale. Thereafter, the measures were gradually relaxed, depending on the specific situation in each territory. When an increase in transmission was detected in early August, they were reinforced.

The heterogeneous evolution of the epidemic in the provinces is mainly attributable to factors affecting transmission of the virus, such as degree of urbanization, population density, and greater or lesser mobility in the respective territories, and not because greater priority was given to one territory over another. This explains why "de-escalation" — and even in some instances "re-escalation" —of the measures exhibited a different pattern in the capital and surrounding areas compared with the rest of the country.

It should be emphasized that the case-fatality rates recorded in Cuba are similar to the three strata identified above: (low: 2.73; intermediate: 1.84 , and high: $2.01 ; p=0.80$ ). These results reflect not only the quality of the treatment protocols used but 
also the fact that their application has been uniform in all the country's territories.

To achieve sustainability and maintain equity in the control and treatment of COVID-19, it was-and continues to beessential to provide the entire SNS network with diagnostic supplies for RT-PCR testing, medicines, equipment, and personal protective gear, among other resources. The challenge of coming to grips with the pandemic arose at a time when Cuba was also subjected to a tightening of the economic and financial embargo imposed by the Government of the United States of America, which prohibited financial resources from entering the country and blocked the importation of medicines and other necessary items for combating the pandemic. This situation posed an enormous additional obstacle that the country had to overcome in order to maintain conditions of equity as it was facing a critical epidemiological and health care scenario and the urgency of combating the pandemic (17).

As to the behavior of COVID-19 in the country, after transmission peaked in mid-April, with an incidence rate of 6.49 cases per 100000 population, by the end of July the disease was briefly under control. However, in September the number of confirmed cases began to climb again, reaching a new peak of 7.43 cases per 100000 population. The subsequent decline in the incidence rate and control of transmission are evidence that the Cuban SNS has the capacity to deal with the next challenge: a persistent disease with recurring outbreaks; in other words, a period during which we have to learn to live with the disease and face challenges related to international health control, isolation of contacts at the primary care level, and acquisition and administration of a vaccine at population scale. At the time of this article's publication, Cuba is in the process of developing several candidate vaccines, two of which are already in human clinical trials.

Cuba's experience has enabled the country to find solutions to problems and obstacles as they have arisen. This learning process in response to the challenges has led to a series of measures that have made it possible to bring the pandemic under control in Cuba. It has also provided lessons that will be useful in other similar contexts (Table 2).

Cuba

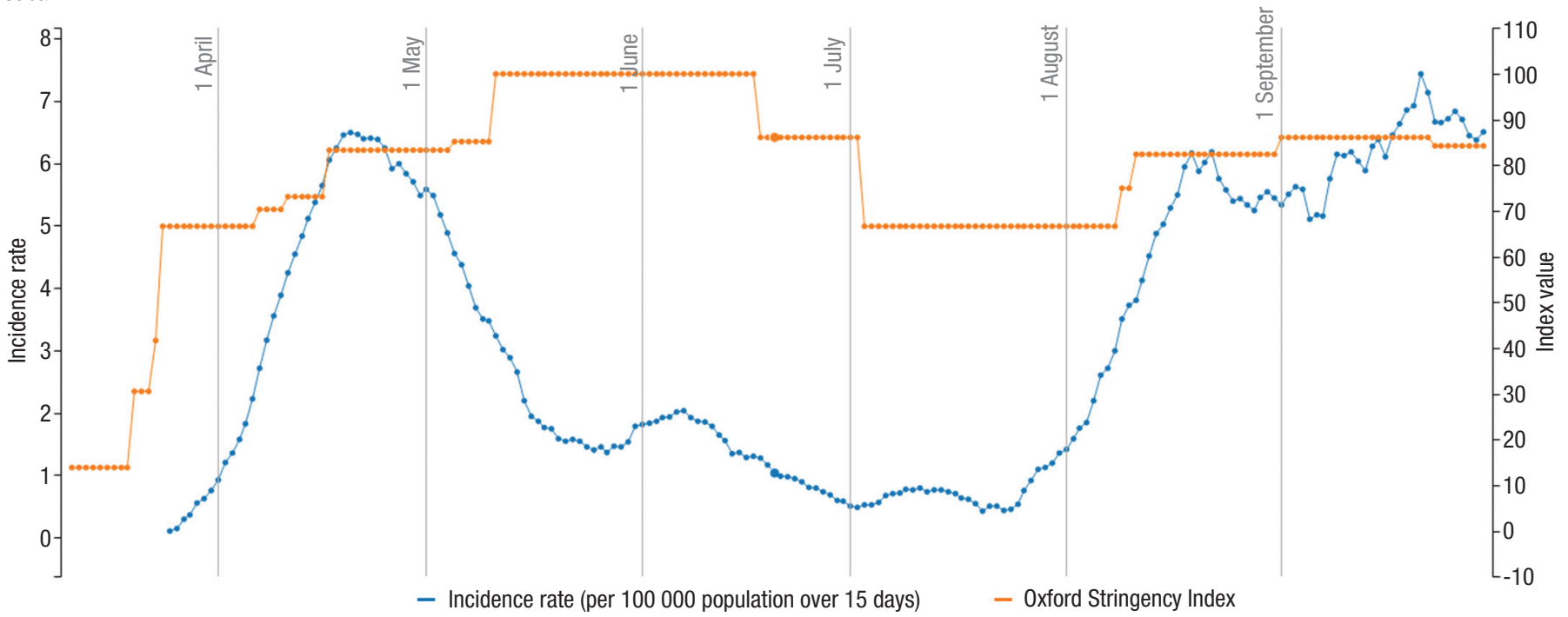

Source: Own preparation based on data from: https:Itcovid19cubadata.github.iof\#cuba

The Oxford Stringency Index, or COVID-19 Government Response Tracker, assesses the degree of severity or restrictiveness of government responses to COVID-19 (31).

TABLE 2. Lessons learned during control and management of the COVID-19 pandemic, Cuba, 2020

Dimensions

Preparedness

Epidemiologica

surveillance
Challenges

Actions taken

Spread of the SARS-CoV-2 epidemic throughout the world, as reported by the World Health Organization

Facing an unknown disease
- Expression of political will by the Government to confront and control the disease

- Development of Plan for Coronavirus Prevention and Control

- Creation of Temporary National Working Group to Fight COVID-19 based on intersectoral action

- Development of communication policies, including the use of mass media and social networks to share messages with the population

- Adjustments in the allocation of existing material resources

- Training of human resources

- Deployment of the Epidemiological Surveillance System with key elements for risk identification

- Promotion of community participation, social mobilization, and behavior modification for prevention and control of the disease 
TABLE 2. Lessons learned during control and management of the COVID-19 pandemic, Cuba, 2020 (continued)

\begin{tabular}{|c|c|c|}
\hline Dimensions & Challenges & Actions taken \\
\hline Active case finding & $\begin{array}{l}\text { High transmissibility of the virus } \\
\text { Lack of knowledge regarding seroprevalence in the } \\
\text { population }\end{array}$ & $\begin{array}{l}\text { - Mobilization of the primary care system with added support from medical students } \\
\text { - Early detection through tracking; isolation of positive cases and their contacts } \\
\text { - Identification of severe forms of the disease and vulnerable groups with preexisting } \\
\text { conditions }\end{array}$ \\
\hline Diagnostic tests & Novelty and cost of diagnostic testing for SARS-CoV-2 & $\begin{array}{l}\text { - Establishment of a molecular biology laboratory network for molecular diagnosis using re- } \\
\text { al-time polymerase chain-reaction (RT-PCR) testing }\end{array}$ \\
\hline Biosafety & $\begin{array}{l}\text { Elevated risk due to form of transmission (airborne } \\
\text { and by contact) and its high transmissibility }\end{array}$ & $\begin{array}{l}\text { - Development of protocols and provision of biosafe environments and protective equipment } \\
\text { for health personnel }\end{array}$ \\
\hline $\begin{array}{l}\text { Therapeutic } \\
\text { interventions }\end{array}$ & Need for specific and precise treatments & $\begin{array}{l}\text { - Creation of preventive and therapeutic models and protocols } \\
\text { - Development of first-line medicines within the country }\end{array}$ \\
\hline Case fatality & $\begin{array}{l}\text { Need to keep people from getting sick, suffering from } \\
\text { complications, or dying }\end{array}$ & $\begin{array}{l}\text { - Establishment of research-based preventive and therapeutic measures with a view to } \\
\text { keeping the healthy population from getting sick; if they get sick, keeping their illness } \\
\text { from getting worse; if it does get worse, keeping them from dying; and if they do not die, } \\
\text { keeping them from having long-term effects } \\
\text { - Establishment of behavior- and treatment-related standards according to a protocol that } \\
\text { specifies the steps to take at each point in the evolution of the disease } \\
\text { - Engagement of the Cuban biomedical and biotechnological industry in the development and } \\
\text { application of innovative disease-specific drugs, equipment, and vaccines }\end{array}$ \\
\hline Equity & $\begin{array}{l}\text { Need for health services to be equitable while not } \\
\text { becoming overtaxed }\end{array}$ & $\begin{array}{l}\text { - Arrangements to ensure that all services, including prevention, diagnosis, isolation, hospi- } \\
\text { talization, and intensive care, are free of cost and universally available } \\
\text { - Intersectoral and community-level outreach in support of all actions } \\
\text { - Readaptation and enhanced capacity of the health services } \\
\text { - Diagnostic tests free of cost for the entire at-risk population } \\
\text { - Control and active follow-up of confirmed and suspected cases }\end{array}$ \\
\hline
\end{tabular}

\section{CONCLUSIONS}

The organization of Cuba's SNS and the effectiveness of its response to COVID-19 have been based on the premise of guaranteeing equity in health systems and providing services that are accessible and free of cost to all citizens. Since these conditions were already in place before the pandemic reached Cuba, it was possible to tackle COVID-19 in the country with positive results starting from day one of the pandemic. This experience has also provided numerous lessons that have enriched its strategy for dealing with other extreme situations using the same key elements: development of a single nationwide plan, use of specific research strategies, diagnosis and contact tracing, implementation of a single protocol for the treatment and management of confirmed cases, and a government-wide and intersectoral response. These elements have made it possible to control the disease in Cuba while also upholding the principle of equity in health.

Authors' contributions. PMB (https://orcid.org/ 0000-00025350-657X), LSV (https:/ / orcid.org/0000-0001-7747-1052), MVL (https://orcid.org/0000-0002-0293-5999), ASJ (https://orcid .org/0000-0002-2231-0822), and RMO (https: / / orcid.org/00000001-9251-7127) conceived the original study. LSL (https:// orcid.org/0000-0002-9399-7238) and YAC (https:// orcid.org
/0000-0002-2345-1387) collected the data. LSV, YAC, MVL, ASJ, PMB analyzed and interpreted the results. PMB, LSV, MVL, CVO (https://orcid.org/0000-0003-0276-6264) and IAS (https:/ / orcid.org/0000-0003-2296-5041) wrote the manuscript and reviewed the literature. All authors read and approved the final version of the manuscript.

Acknowledgments. The authors wish to express their thanks to the editor and the reviewers for their comments, which made it possible to improve the manuscript. They also want to thank Daniel González and Lisset López for information on vulnerability, risks, and the case management protocol for cases in adults and pediatric patients, respectively.

Conflict of interests. The authors do not declare any conflict of interests, although they have participated in development of the strategies analyzed in the article.

Funding. This study did not receive any funding.

Disclaimer. Authors hold sole responsibility for the views expressed in the manuscript, which may not necessarily reflect the opinion or policy of the Revista Panamericana de Salud Pública / Pan American Journal of Public Health or the Pan American Health Organization (PAHO).

\section{REFERENCES}

1. Sánchez P. Ética nicomáquea, ética eudemia. Madrid: Gredos; 1988 [accessed 18 July 2020]. Available from: http://www.posgrado. unam.mx/filosofia/pdfs/Aristoteles_Etica-a-Nicomaco-Etica-Eudemia-Gredos.pdf

2. Equidad. Significados.com [Internet]; 2020 [accessed 18 July 2020]. Available from: https://www.significados.com/equidad/
3. España, Ministerio de Sanidad, Consumo y Bienestar Social. Equidad en salud y desigualdades sociales en salud [Internet]. Madrid: MSCBS; 2020 [accessed 18 July 2020]. Available from: https: / / www.mscbs.gob.es/profesionales/saludPublica / prevPromocion/promocion / desigualdadSalud / Equidad SaludyDSS.htm 
4. Cuba, Ministerio de Salud Pública. Parte de cierre del día 1.o de octubre a las 12 de la noche. La Habana: MINSAP; 2020 [accessed 26 October 2020]. Available from: https://salud.msp. gob.cu/ parte-de-cierre-del-dia-1-de-octubre-a-las-12-de-la-noche /

5. Shamasunder S, Holmes SM, Goronga T, Carrasco H, Katz E, Frankfurter $\mathrm{R}$, et al. COVID-19 reveals weak health systems by design: Why we must re-make global health in this historic moment. Glob Public Health. 2020;15(7):1083-9 [accessed October 2020]. Available from: https://www.tandfonline.com/doi/full/10.1080/1 7441692 .2020 .1760915

6. Pan American Health Organization. Promoting health equity, gender and ethnic equality, and human rights in COVID-19 responses: Key considerations. Washington, DC: PAHO; 2020 [accessed 3 August 2020]. (OPS/EGC/ LEG/COVID-19-0001). Available from: https://iris.paho.org/handle/10665.2/52058

7. Zabala MC, Fundora G. Retos para la equidad social en el proceso de actualización del modelo económico cubano. Perf Cult Cubana. 2019;25:231-3 [accessed 18 July 2020]. Available from: http:// www.perfiles.cult.cu/articulos/9\%20Perfiles-num25-Zaba- la_Md-C.pdf

8. Cuba. Constitución de la República. Granma. 2019 April 9 [accessed 18 July 2020]. Available from: http://www.granma.cu/file/pdf/ gaceta/Nueva $\% 20$ Constituci $\%$ C3\%B3n $\% 20240 \% 20 \mathrm{~KB}-1$. pdf

9. Morales R, Mas P, Castell-Florit P, Arocha C, Valdivia NC, Druyet $\mathrm{D}$, et al. Transformaciones en el sistema de salud en Cuba y estrategias actuales para su consolidación y sostenibilidad. Rev Panam Salud Publica. 2018;42:e25 [accessed 18 July 2020]. Available from: https:/ / doi.org/10.26633/RPSP.2018.25

10. Di Fabio HL, Gofin R, Gofin J. Análisis del sistema de salud cubano y del modelo de atención primaria orientada a la comunidad. Rev Cubana Salud Publica. 2020;46(2):e2193 [accessed 18 July 2020]. Available from: http://www.revsaludpublica.sld.cu/index. php/ spu/article/view/2193/

11. Pérez B. La equidad en los servicios de salud. Rev Cubana Salud Publica. 2007;33(3) [accessed 4 August 2020]. Available from: http://scielo.sld.cu/pdf/rcsp/v33n3/spu07307.pdf

12. Castell-Florit P, Acevedo Martínez M, Vidal Ledo MJ. La intersectorialidad en Cuba es una fortaleza para el enfrentamiento a la COVID-19. Infodir. 2020;33:e836 [accessed 12 May 2020]. Available from: http:/ / www.revinfodir.sld.cu/index.php/infodir/article/view/836/

13. Cuba, Ministerio de Salud Pública. Anuario Estadístico de Salud, 2019. La Habana: Dirección de Registros Médicos y Estadísticas de Salud; 2020 [accessed 12 May 2020]. Available from: https:// files.sld.cu/bvscuba / files / 2020 / 05 / Anuario-Electr\%c3\%b3nico-Es-pa\%c3\%b1ol-2019-ed-2020.pdf

14. Corral A, Pría MC. Diseño de un índice de condiciones de vida y clasificación del territorio nacional. Rev Med Gen Integral. 2017;31(3):323-32 [accessed 4 August 2020]. Available from: http:/ / scielo.sld.cu/pdf/v31n3/mgi073015.pdf

15. Whitehead M. The concepts and principles of equity and health. Int J Health Serv. 1992;22(3):429-45. doi: 10.2190/986L-LHQ6-2VTEYRRN. PMID: 1644507

16. Cuba, Ministerio de Salud Pública. Plan de prevención y control de la COVID-19, estrategia para estar debida y oportunamente preparados. La Habana: MINSAP; 2020 [accessed 4 August 2020]. Available from: https://www.presidencia.gob.cu/ es/noticias/ plan-de-prevencion-y-control-del-covid-19-estrategia-para-estardebida-y-oportunamente-preparados /

17. Díaz-Canel M, Núñez-Jover J. Gestión gubernamental y ciencia cubana en el enfrentamiento a la COVID-19. An Acad Cienc Cuba. 2020;10(2) [accessed 22 June 2020]. Available from: http://www. revistaccuba.cu/index.php/revacc/article/view/881/886

18. Cuba, Ministerio de Salud Pública. Plan de Prevención y Control para el Enfrentamiento a la COVID-19. La Habana: MINSAP; 2020.

19. Más P, Vidal M, Baldoquin W, Seuc AH, Guinovart R, Pérez N, et al. Organización de la investigación epidemiológica para la lucha antiepidémica contra la COVID-19 en Cuba. Infodir. 2020 [accessed
12 May 2020]; 33:e831. Available from: http://revinfodir.sld.cu/ index.php/infodir/article/view/831/ 1103

20. Cuba informa 40 medidas para el enfrentamiento al nuevo coronavirus COVID-19. Granma. 2020 marzo 24 [accessed 25 March 2020]. Available from: http://www.granma.cu/cuba-covid-19/2020-03 -24/el-primer-secretario-del-pcc-y-el-presidente-activaron-los-con sejos-de-defensa-en-el-pais-24-03-2020-01-03-10

21. Reyes S, Fernández J. ¿Se puede evaluar la respuesta de un gobierno ante la COVID-19? CubaData. 2020 [accessed 5 May 2020]. Availablefrom:http:/ / www.acn.cu/cuba/64175-se-puede-evaluar-larespuesta-de-un-gobierno-ante-la-covid-19

22. Cuba, Ministerio de Salud Pública. Coronavirus en Cuba. Información Oficial del MINSAP. La Habana: MINSAP; 2020 [accessed 16 August 2020]. Available from: https://salud.msp.gob.cu/

23. Cuba, Ministerio de Salud Pública. Protocolo de actuación nacional para la COVID-19. La Habana; 2020 [accessed 26 August 2020]. Available from: http:/ / files.sld.cu/editorhome/files/2020/08/version-5-del-protocolo-para-publicar-13-de-agosto-2020.pdf

24. Galván-García E, Mas Bermejo P. COVID-19 in Cuba: Assessing the national response. MEDICC Rev. 2020;22(4) [accessed 30 October 2020]. Available from: https://mediccreview.org/ covid-19-in-cuba-assessing-the-national-response/

25. López L, Noda A, Castro B, Cruz SM, Causa N, Cabrera L, et al. Caracterización clínico epidemiológica de 183 niños cubanos con infección por SARs-COV2. Rev Cubana Pediatr. 2020;92 Suppl:e1256 [accessed 2 October 2020]. Available from: http://www. revpediatria.sld.cu/index.php/ped/article/view/1256

26. Saavedra D, Fuertes SA, Suárez GM, González A, Lorenzo-Luaces $\mathrm{P}$, García B, et al. Biomodulina $\mathrm{T}$ partially restores immunosenescent CD4 and CD8 T-cell compartments in the elderly. Exp Gerontol. 2019;124 [accessed 2 October 2020]. Available from: https://www.sciencedirect.com/science/article/abs/pii/S0531 556518305850

27. Saborit A. Presencia de la medicina natural y tradicional en la batalla contra la COVID-19. Rev 16 Abril. 2020;59(277):e978 [accessed 5 May 2020]. Available from: http:/ / www.rev16deabril.sld.cu/index. php/16_04/article/view/978

28. Bello-Rivero I, García-Vega Y, Ducan-Roberts Y, Vázquez-Blomquists D, Santana-Milián H, Besada-Pérez V, et al. HeberFERON, a new formulation of IFNs with improved pharmacodynamics: Perspective for cancer treatment. Semin Oncol. 2018;45:27-33 [accessed 5 May 2020]. Available from: https://www.sciencedirect.com/ science/article/abs/pii/S0093775418300915

29. Hernández P, Moreno E, Aira LE, Rodríguez PC. Therapeutic targeting of CD6 in autoimmune diseases: A review of Cuban clinical studies with the antibodies IOR-T1 and Itolizumab. Curr Drug Targets. 2016;17(6):666-77 [accessed 2 October 2020]. Available from: https:/ / europepmc.org/article/med/26844560

30. Venegas-Rodríguez R, Santana-Sánchez R, Peña-Ruiz R, BequetRomero M, Hernández-Cedeño M, Santiesteban-Licea B, et al. CIGB-258 immunomodulatory peptide: a novel promising treatment for critical and severe COVID-19 patients. MedRxiv Reprints; 2020. doi: https:/ / www.medrxiv.org/content/10.1101/2020.05.27.2 0110601v1.full.pdf

31. Hale T, Webster A, Petherick A, Phillips T, Kira B. Oxford COVID19 government response tracker. Oxford, UK: University of Oxford, Blavatnik School of Government; 2020 [accessed 5 May 2020]. Available from: https://www.bsg.ox.ac.uk/research/research-projects/ coronavirus-government-response-tracker

Manuscript (original in Spanish) received on 24 August 2020. Revised version accepted for publication on 19 October 2020 


\section{Equidad y respuesta del Sistema Nacional de Salud de Cuba ante la COVID-19}

RESUMEN El Sistema Nacional de Salud de Cuba ha logrado garantizar una respuesta eficaz y con equidad en el enfrentamiento a la COVID-19. La cobertura de salud universal y gratuita, basada en la atención primaria, sigue el principio de equidad, por lo que los mayores recursos se asignan a los territorios del estrato socioeconómico más bajo, que concentra mayores riesgos de salud, seguidos de los de estratos medio y alto, en ese orden. Esto permitió tener tasas de letalidad similares en los tres estratos, y a nivel nacional la de Cuba es una de las tasas más bajas de la Región de las Américas. Antes de identificar el primer caso en Cuba, se elaboró el Plan para la Prevención y Control del Coronavirus, con participación multisectorial, y al confirmarse el primer caso se creó el Grupo Temporal de Trabajo para Enfrentar la COVID-19 como órgano asesor del Gobierno. Las acciones de enfrentamiento a la pandemia comienzan en la comunidad con medidas preventivas, continúan en los centros de aislamiento y terminan nuevamente en la comunidad, con acciones de vigilancia y acompañamiento a los enfermos recuperados. Siguiendo el principio de territorialidad, se crearon laboratorios de diagnóstico molecular en las provincias que no lo tenían. La atención médica y los tratamientos gratuitos; la preparación de un plan de gobierno intersectorial nacional único; la utilización de estrategias particulares para la pesquisa, diagnóstico y rastreo de casos; y la implementación de un protocolo universal para la prevención de la enfermedad y el tratamiento de los casos confirmados permitieron el control de la enfermedad con una perspectiva de equidad en salud.

Palabras clave Infecciones por coronavirus; equidad en salud; cobertura universal de salud; atención primaria de salud; Cuba.

\section{Equidade e resposta do Sistema Nacional de Saúde de Cuba à pandemia de COVID-19}

RESUMO O Sistema Nacional de Saúde de Cuba tem assegurado uma resposta eficaz e com equidade ao enfrentar a pandemia de COVID-19. A cobertura de saúde universal e gratuita baseada na atenção primária se pauta no princípio da equidade. Mais recursos são destinados às áreas de nível socioeconômico mais baixo que concentram risco de saúde maior e a seguir, nesta ordem, às áreas de nível socioeconômico médio e alto. Assim, a taxas de letalidade tem sido semelhante nos três níveis e a taxa nacional é uma das mais baixas da Região. Antes de o primeiro caso de COVID-19 ter sido detectado em Cuba, preparou-se o Plano para prevenção e controle do coronavírus com participação multissetorial. Quando o primeiro caso da doença foi confirmado, instituiu-se o Grupo de trabalho temporário para combater a COVID-19 como um órgão assessor do governo. As ações de combate à pandemia começam na comunidade com medidas preventivas, prosseguem nos centros de isolamento e retornam à comunidade com medidas de vigilância sanitária e o acompanhamento dos pacientes recuperados. E, seguindo o princípio de territorialidade, laboratórios de diagnóstico molecular foram instituídos nas províncias onde eles inexistiam. A atenção médica, o tratamento gratuito, a preparação de um plano de governo único intersetorial nacional, o emprego de estratégias próprias para pesquisa, diagnóstico e rastreio de casos e a implementação de um protocolo universal para prevenção da doença e tratamento dos casos confirmados possibilitaram controlar a doença de uma perspectiva de equidade em saúde.

Palavras-chave Infecções por coronavirus; equidade em saúde; cobertura universal de saúde; atenção primária à saúde; Cuba. 